\title{
A Preservice Teacher's Reflections on Education for Sustainable Development in Multiple-Deprived Science Classrooms
}

\author{
Dr Maria Tsakeni ${ }^{1} \&$ Prof Loyiso Jita ${ }^{1}$ \\ ${ }^{1}$ University of the Free State, South Africa \\ Correspondence: Dr Maria Tsakeni, University of the Free State, Private Bag X13, Phuthaditjhaba, 9866, RSA, South \\ Africa. \\ Received: February 7, 2021 \\ Accepted: April 13, 2021 \\ Online Published: April 16, 2021 \\ doi:10.5430/ijhe.v10n5p56 \\ URL: https://doi.org/10.5430/ijhe.v10n5p56
}

\begin{abstract}
In the wake of the United Nations' Agenda 2030 on sustainability, this study problematizes how conditions in multiple-deprived science classrooms are intricately connected to the sustainable development goals (SDGs). This narrative inquiry design research consisting of one participant, describes how the conditions of multiple-deprivation in science classrooms are influenced by, and in turn influence the achievement of, some of the SDGs. The narratives were contained in the reflections documented by a Bachelor of Education (BEd) preservice physical sciences teacher of his third- and fourth-year teaching practice experiences whilst conducting observations and teaching in multiple-deprived classrooms. The study was undergirded by education for sustainable development (ESD) and the SDGs as conceptual frameworks. The data collected were analysed through narrative data analysis techniques, revealing forms of deprivation in the science classroom which were driven by the SDGs related to poverty elimination, quality education, reduction of inequalities and social injustice, promotion of sustainable communities, and establishment of partnerships for goal attainment. The study findings show how the teaching and learning in multiple-deprived classrooms may pose as a challenge to the attainment of the SDGs, pointing out to some implications for practice.
\end{abstract}

Keywords: education for sustainable development, multiple-deprived science classrooms, preservice teachers, sustainable development

\section{Introduction}

Inclusive and equitable access to quality education is one of the sustainable development goals (SDGs), according to the United Nations' Agenda 2030. However, multiple-deprived science classrooms experience unique sustainable development issues that compromise the attainment of the goal for inclusive and equitable access to quality education. Some of these sustainable development issues are intricately connected to the conditions of multiple deprivation in science classrooms. The SDGs are embodied in Agenda 2030 that was adopted by heads of government at a United Nations summit in 2015 (UN, 2015). Agenda 2030's pronouncement of 17 SDGs and 169 targets is a clear indication of the existence of some unmet needs globally. The unmet needs give way to conditions of deprivation. Conditions of multiple deprivation result from a confluence of unmet needs in the lives of people (Noble, Zembe, Wright, \& Avenell, 2013). Maringe, Masinire, and Nkambule (2015) defined multiple deprivation as a combination of factors that work against the developmental aspects of a group of people. Upon considering the SDGs, some of the unmet needs pertain to the issues of hunger, health, poverty, water quality, proper sanitation, and health of the land, air, and sea (UN, 2015). The SDGs are an imperative of the sustainable development initiatives of meeting the present-day needs of individuals and communities without compromising the needs of future generations (Eilks, 2015). For example, the goal to end hunger is not just about making sure that everyone has sufficient nutrition, but the food must be made available through sustainable practices.

The SDGs also speak to issues of social justice, inclusivity, economic growth, and an end to human suffering caused by the unmet needs. Some of these aspects of the SDGs are topics in science education, which strategically positions the subject for the teaching of education for sustainable development (ESD). ESD is a process of teaching young people going through the education systems to be responsible for their actions in the future by participating in development activities in sustainable ways (Burmeister, Rauch, \& Eilks, 2012). ESD does not target young people only, however, but includes all citizens in order for them to start working towards sustainable development through actively participating in developmental and democratic processes in societies. Hence, ESD can either be formal or 
informal. The teaching of science is one of the development activities in which young people (learners) and adult citizens (teachers and other stakeholders) participate.

In light of the current multiple-deprivation conditions in the form of unmet needs, ESD aims to equip citizens with skills to correct and redress the conditions of multiple-deprivation so that these conditions may not repeat themselves in the future. ESD is an imperative of sustainable development initiatives in which development is seen as meeting the needs of the people on planet earth without compromising the needs of future generations. One model of sustainable development places it broadly to encompass the development activities of the people in social, economic, and environmental dimensions (Muralikrishna \& Manickam, 2017). However, the development issues can be more specific to relate to particular aspects of people's lives, such as defined by the indicators embodied in the SDGs and more. One of the SDGs focuses on the attainment of inclusive and equitable access to quality education by the year 2030 (UN, 2015). Education is practised in various contexts and at different levels. The science-education context portrays unique issues in terms of unmet needs that lead to multiple-deprived science classrooms, which in turn points to inclusivity, equitable access, and quality-education challenges. For example, Cho, Scherman, and Gaigher (2014) pointed out that the poor performance of learners in science and mathematics may be influenced by factors that stem from their low socioeconomic status. In South Africa, conditions of multiple deprivation may be associated with some schools in rural areas, townships, and farms because of their lack of resources and ineffective school improvement plans, amongst other challenging conditions (Chikoko, 2018). In this paper, the conditions of multiple deprivation in science classrooms are regarded as all those factors that stand in the way of effective teaching and learning. In science education, conditions of multiple deprivation are associated with inadequate teacher professional identities, lack of resources, ineffective teaching and learning strategies, and learner participation, amongst other factors. Therefore, the preparation of teachers is essential to ensure that they work effectively in the different school contexts in ways that support sustainable development. UNECE (2011) emphasized the need for preservice teachers to develop the competencies necessary for the implementation of ESD in ways that holistically address the sustainable development challenges. Holistic models of sustainable development should first and foremost encompass the three main ESD pillars, social, economic, and environmental (Burmeister et al., 2012; Eilks, 2015). Based on the preceding background, this study seeks to answer the question, how are the conditions of multiple deprivation in science classrooms influenced by, and in turn how do they influence the attainment of, the SDGs? The study contributes to debates on how science education helps in the achievement of the SDGs and how access to quality education (one of the SDGs) is compromised in multiple-deprived science classrooms.

\section{Literature Review}

\subsection{Science Education and the SDGs}

Agenda 2030, like its predecessors, such as the decade for education for sustainable development (2005-2014) and the millennium development goals, puts a timeline to what should be achieved through the sustainable development initiatives. Agenda 2030 has 17 SDGs that serve as indicators or drivers for sustainable development (UN, 2015). The SDGs are both inter- and multi-disciplinary in nature and are articulated as what should be achieved when development becomes sustainable. Table 1 summarizes the 17 SDGs.

Table 1. Sustainable development goals

\begin{tabular}{llllll}
\hline 1. No poverty & 2. Zero hunger & $\begin{array}{l}\text { 3. Good health } \\
\text { and well-being }\end{array}$ & $\begin{array}{l}\text { 4. Quality } \\
\text { education }\end{array}$ & $\begin{array}{l}\text { 5. Gender } \\
\text { equality }\end{array}$ & $\begin{array}{l}\text { 6. Clean water } \\
\text { and sanitation }\end{array}$ \\
\hline $\begin{array}{l}\text { 7. Affordable } \\
\text { and clean } \\
\text { energy }\end{array}$ & $\begin{array}{l}\text { 8. Decent work } \\
\text { and economic } \\
\text { growth }\end{array}$ & $\begin{array}{l}\text { 9. Industry, } \\
\text { innovation, and } \\
\text { infrastructure }\end{array}$ & $\begin{array}{l}\text { 10. Reduced } \\
\text { inequalities }\end{array}$ & $\begin{array}{l}\text { 11. Sustainable } \\
\text { cities and } \\
\text { communities }\end{array}$ & $\begin{array}{l}\text { 12. Responsible } \\
\text { consumption } \\
\text { and production }\end{array}$ \\
$\begin{array}{l}\text { 13. Climate } \\
\text { change }\end{array}$ & $\begin{array}{l}\text { 14. Life below } \\
\text { water }\end{array}$ & 15. Life on land & $\begin{array}{l}\text { 16. Peace, } \\
\text { justice, and } \\
\text { strong } \\
\text { institutions }\end{array}$ & $\begin{array}{l}\text { 17. } \\
\text { Partnerships for } \\
\text { the goals }\end{array}$ & \\
& & & &
\end{tabular}

Science education has a significant role to play in sustainable development because some of the aspects of the SDGs speak directly to some of the topics taught in science subjects. Looking at SDGs nos. 6 and 7, for example, we see that topics such as water purification and electricity generation are some of the topics contained in science curriculums, including the South African physical sciences curriculum (Department of Basic Education, 2011). The goal on climate change (no. 13) can be linked to topics such as fossil fossils and the production of alternative fuels. Towards that goal, Karpudewan, Ismail, and Mohamed (2009) used the synthesis of biodiesel as one topic covered when integrating 
sustainability in the methods courses for science preservice teachers. The $12^{\text {th }} \mathrm{SDG}$, on responsible consumption (Table 1), is aligned to some of the green-chemistry principles by Anastas and Warner (1998). The green-chemistry principle of atom economy encourages the maximization and incorporation of all materials during chemical synthesis to avoid wastefulness. The principles also emphasize the importance of energy efficiency and reduction of waste production. Based on these few illustrations, it can be acknowledged that science can be directly linked to a significant number of the SDGs. There is a general belief that developments in science and technology are crucial for the achievement of the SDGs.

Science education as a field and practice has a role to play under the fourth SDG on achieving inclusive and equitable access to quality education in addition to promoting life-long-learning opportunities. Science education plays its part in preparing learners to participate meaningfully in some economic sectors based on the belief that science and technology contribute to shaping global economies (Clothey, Mills, \& Baumgarten, 2010). Scientific literacy as one of the science education goals is also linked to improved lifestyles, where citizens make informed decisions on important aspects such as nutrition, health, and environmental protection (Holbrook, 2009).

\subsection{Conditions of Multiple Deprivation in Science Classrooms}

Conditions of multiple deprivation refer to the different unmet needs in the teaching and learning of science. Multiple deprivation is a social condition resulting from an accumulation of single domains of unmet needs (Noble et al., 2013). These unmet needs may include conditions of poverty and result in the classification of individuals and communities under low socio-economic status. Some of the unmet needs have their roots in impoverished and disadvantaged historical backgrounds. Such is the case with the South African school-context landscape, where it is common to have schools classified by their historical origins, such as African township, rural and farm, former model C (schools formerly dedicated to White learners only under apartheid), former Coloured, former Indian, private, and independent. Unfortunately, some of these school contexts continue to display characteristics of multiple deprivation partly brought about by their impoverished and disadvantaged historical backgrounds (Selod \& Zenou, 2003). One of the significant forms of deprivation in schools for science teaching and learning is the lack of learning materials for practical work. Some research studies associate the lack of resources to some prevalent teaching strategies in science classrooms. For instance, Christie, Carey, Robertson, and Grainger (2007) confirmed that in some South African schools, the teaching and learning of science is done without the practical component because of lack of facilities and materials. What gives is a situation where most classrooms in southern Africa are dominated largely by explicit instructional practices (Ottevanger, Van den Akker, \& De Feiter, 2007; Ramnarain \& Schuster, 2014). Explicit teaching strategies rely heavily on teacher explanations and demonstrations and focus mainly on covering the content in time for inevitable assessments (Lunetta, Hofstein, \& Clough, 2007). These teacher-centred instructional strategies contradict the prescriptions of science syllabuses which have inquiry as an underlying theme.

\subsection{The Teaching of ESD in Science Classrooms}

The concept of sustainable development is based on a goal for public good since it encourages the present generations to be able to meet their needs without compromising the needs of future generations (Eilks, 2015). However, multiple-deprived environments are characterized by a state of unmet needs, some of which may be as a result of socio-economic inequalities and social injustices. Although sustainable development is said to basically hinge on the three pillars of the social, economic, and environmental aspects of people's lives, these are, however, value-laden and can be extended to apply in other spheres such as politics, culture, and education (Berglund \& Gericke, 2016). The education aspect of sustainable development in what is conceptualized as ESD is important to ensure that learners develop citizen skills for sustainability. The advent of ESD came with a number of implementation approaches in the science classroom. One of the goals for ESD is to inculcate values, ethics, and behaviours that promote citizen skills for sustainable development in young people (Schild, 2016). As Holbrook (2009, p. 44) propounded, "[i]t is suggested that education for sustainable development has little to do with accumulating a body of scientific knowledge and is far more aligned with the development of personal and social aptitudes leading to responsible citizenship." How values, ethics, and behaviours can be promoted in learners through classroom practice is not very clear. However, what is clear is that science education can be used as a medium to teach ESD. It may be assumed that, currently, the practices in education are not sufficient to prepare learners for sustainable development because Sipos, Battisti, and Grimm (2008) posited that unsustainability is a result of the education practices that have been in place. One of the approaches to teach ESD recognizes that the practice of science as a discipline and its relationship with the environment must be sustainable. This approach shows how science education puts more emphasis on the environmental pillar of sustainable development than the social and economic pillars. Accordingly, sustainable science or green science, which refers to practices in which science knowledge is applied in ways that reduce the impact of 
human activities on the environment, is taught. Green/sustainable science may be broken down to green/sustainable physics, green/sustainable chemistry and many other similar fields. For example, Karpudewan, Ismail, and Roth (2012, p.121) said that,

... green chemistry refers to the use of chemistry that prevents pollution. In order to prevent pollution, green chemistry employs materials, processes, or practices that reduce or eliminate the creation of pollutants or wastes. The term also refers to practices that reduce the use of hazardous and non-hazardous materials, energy, water, or other resources as well as protect natural resources through efficient use.

The practice of green science is reflected in some classroom practices, such as laboratory work. Laboratory and practical work are inherent to science education in methods of knowing and instructional strategies. These instructional strategies may involve the use of materials and processes that may release wastes and pollutants into the environment. This condition of unsustainability is being replaced by a model of green science in which less hazardous materials and practices are becoming part of the school laboratory or practical work curriculum (Burmeister et al., 2012). The practice of green science is also reflected in some higher education science programs. Andraos and Dicks (2012) mentioned that significant successes in employing green science are reflected in the optimized synthesis of organic compounds, some of which have pharmaceutical importance. It can be implied that students who attend such kinds of programs may develop the knowledge and skills underlying the practice of green science that are transferable to their future practices in related fields. Sustainable science ensures that human activities have a reduced impact on the environment. It can be assumed that a reduction on the environmental impact will also positively influence the lives of people in the social and economic dimensions of sustainable development.

However, as Andraos and Dicks (2012) pointed out, sustainability is integrated under optional topics in school science and appear in very few undergraduate programs. Therefore, the integration of sustainability strategies as science topics (Burmeister et al., 2012) is another way to teach ESD, in addition to green-science practices. The practice of green science can be implemented as solution-based science (Warner \& Elsier, 2015). Examples of sustainability strategies include the production of biodiesel and the synthesis of biodegradable plastics. These topics are a direct attempt to address the environmental issues faced by the planet due to the use of fossil fuels and production of plastic waste. ESD is also taught by means of integrating socio-scientific issues in science teaching. Tsakeni (2018) observed that the integration of an SDG topic such as the quality of water with the mining case study of Mapungubwe in the Curriculum and Assessment Policy Statement for Physical Sciences in South Africa is an example of how socio-scientific issues can be used to teach ESD. The case study allows learners to examine the environmental degradation that results from mining activities and the overall impact on the society. The integration of the socio-scientific issues in science teaching seeks to sensitize the learners that some scientific processes, such as mining, can have an impact on the environment and consequently the social and economic well-being of citizens. Similarly, Kopnina (2012) introduced the SDGs as topics in a sustainability program at a vocational college in the Netherlands for the students to engage in reflection and critical discussions. However, Burmeister et al. (2012) alluded to the fact that whilst it is important to generate critical discussions on some crucial socio-scientific topics in light of sustainable development, it is more important for these discussions to end in actions outside of the classrooms. Accordingly, the whole-school-driven approach to teaching ESD is one of the approaches that can extend science teaching sustainability practices beyond the classroom walls (Burmeister et al., 2012; Mogren, Gericke, \& Scherp, 2019). Whole-school-driven ESD activities are particularly concerned with the development of citizen skills for sustainability by putting them into practice as a school culture. Mogren et al. (2019) posited that whole-school-driven ESD programs influence school improvement positively. The four approaches to teach ESD mentioned above can all be used in science teaching to enhance the development of ESD citizen skills.

This study uses a five-pillar ESD conceptual framework which covers the three basic components of sustainable development (social, economic, and environmental pillars) and two more components that relate to the education of individuals in sustainable development (citizen skills and pedagogies for ESD pillars). The conceptual framework is displayed in Figure 1. 


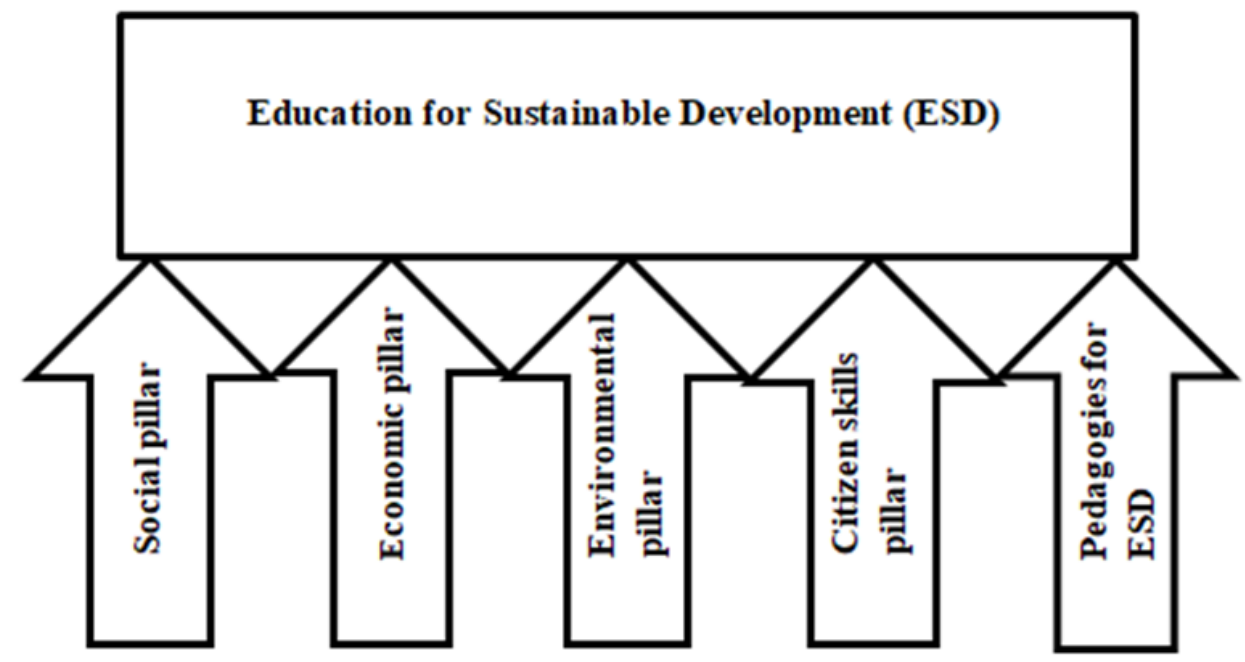

Figure 1. Education for sustainable development conceptual framework (Adopted from Tsakeni, 2018, p. 127)

\section{Study Context and Methods}

The study followed narrative inquiry, a qualitative research design, in which narratives were elicited from a single participant as a way of gathering in-depth data. Whilst the use of multiple cases (individuals) have an advantage of being able to analyse data across the cases, single case studies also have their benefits. Gustafsson (2017) pointed out that the benefits of single case studies include that the researcher can richly describe the existence of a phenomenon and the writer can use the rich data to produce better theory. Gustafssson (2017) also mentioned that a single case study can be constituted of one person or a group of people. Punch (2005) asserted that qualitative data naturally exists as narratives, whilst Bamberg (2012) explained that narratives provide form to experiences and help individuals make sense of what happened. The narratives were documented in a reflection journal in which attention was drawn to the experiences of science teaching and learning as an unmet need.

\subsection{Sample, Instruments, and Procedures}

The research sample consisted of one preservice teacher who was drawn from a class of ten Bachelor of Education (BEd) students in the subject of physical sciences at a university in South Africa. The narratives of the preservice teacher's experiences whilst teaching in multiple-deprived classrooms were used as an entry point to explore some of the challenges of unmet needs in science classrooms. The preservice teacher was purposely selected because he was going to be placed in schools with multiple-deprived science classrooms for his third- and fourth-year teaching practice. The preservice teacher was given the pseudonym Teboho and showed willingness to be part of the study for the last two years of his BEd degree. The multiple-deprived classroom experiences were documented in a reflection journal specially designed to cover the following topics:

- Description of the school contexts and learners' socioeconomic background.

- Description of the resources and materials used in the science classrooms.

- Critical discussion of the instructional strategies used in the science classrooms.

- Teacher preparedness to teach effectively in the multiple-deprived science classrooms.

- Reflections of how to improve the conditions in the science classrooms.

The topics were used to ensure content validity of the data collected. According to Brod, Tesler and. Christensen (2009) the content of qualitative data collection instruments is developed from the researcher's prior knowledge, potential domains of interest to be measured as influenced by the literature reviewed. This particular approach of using reflections to elicit the multiple-deprived conditions of science classrooms is similar to the one employed by Kim and Tan (2011) when they used third-year preservice teachers' reflections to elicit the difficulties of using an innovative instructional strategy in science classrooms. The conditions of multiple-deprivation in science classrooms in this study were filtered through Teboho's teaching practice experiences in a rural school and a township school. The schools were located in Qwaqwa, South Africa, a small town with a combination of townships, rural areas and farms. 


\subsection{Data Analysis}

Teboho's narratives were analysed through a narrative analysis process. Riessman (2005) pointed out that there are several ways to conduct narrative analysis. The steps for narrative analysis as followed by this study are outlined by Blom and Nygren (2010). The researcher (i) read through the data in order to be familiar with it, (ii) read the narratives and conducted a structural analysis focusing on the critical questions on what and how, (iii) developed conceptual codes that aided in comprehending narrative and, lastly, (iv) appropriated the narrative by retelling the story in the findings of the study section. The retold story, organized under six categories, was taken to the participant for member-checking. Table 2 below is an excerpt of the researcher's codebook showing how the concepts were identified and categories developed based on the conceptual frameworks in Table 1 and Figure 1.

Table 2. Excerpt of narratives codebook

\begin{tabular}{|c|c|c|c|}
\hline Code & Description of code & Example of narrative excerpt & Categories \\
\hline $\begin{array}{l}- \text { Socioeconomic and } \\
\text { environmental issues } \\
\text { - SDGs } 1,4,10,11,16, \\
\text { and } 17 \text { (focusing on } \\
\text { poverty, quality education, } \\
\text { inequalities, sustainable } \\
\text { communities, social } \\
\text { justice, and partnerships } \\
\text { for } \\
\text { development, sustainable } \\
\text { respectively) }\end{array}$ & \begin{tabular}{llr}
\multicolumn{2}{c}{ Socioeconomic } & and \\
environmental & issues \\
influencing & teaching and \\
learning & in science \\
classrooms & &
\end{tabular} & $\begin{array}{l}\text { The school is situated at the centre } \\
\text { of the township. It has many } \\
\text { vacant classrooms and labs that are } \\
\text { no longer working. Equipment } \\
\text { were stolen, some are broken. } \\
\text { Some buildings are now neglected. }\end{array}$ & 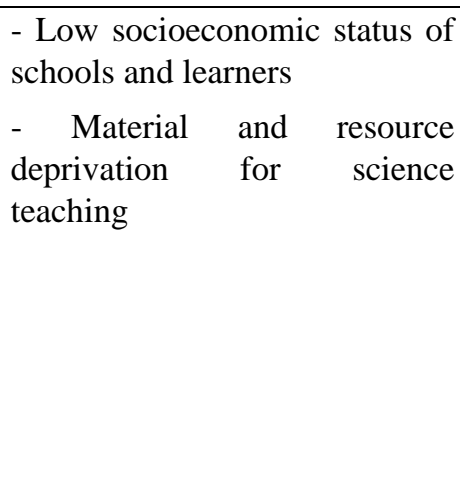 \\
\hline - Citizen skills & - How teaching in & The teachers that I have & - Deprivation of meaningful \\
\hline $\begin{array}{lcl}\text { SDG } & \text { S } & \text { (quality } \\
\text { education) } & & \end{array}$ & $\begin{array}{l}\text { multiple-deprived } \\
\text { classrooms may influence } \\
\text { learning }\end{array}$ & $\begin{array}{l}\text { experience with were using the } \\
\text { instruction technique where they } \\
\text { just present a lesson and expect } \\
\text { learners to just listen }\end{array}$ & $\begin{array}{l}\text { science-learning experience } \\
\text { - Perceptions of addressing the } \\
\text { conditions of multiple } \\
\text { deprivation }\end{array}$ \\
\hline $\begin{array}{l}\text { - Pedagogies for ESD } \\
-\quad \text { SDG } 4 \quad \text { (quality } \\
\text { education) }\end{array}$ & $\begin{array}{l}\text { Instructional strategies used } \\
\text { by teachers in } \\
\text { multiple-deprived } \\
\text { classrooms }\end{array}$ & $\begin{array}{l}\text { The practical work activities were } \\
\text { not implemented, learners only } \\
\text { wrote the practical activities from } \\
\text { the teacher's guide }\end{array}$ & $\begin{array}{l}\text { - Instructional strategy } \\
\text { deprivation } \\
\text { - Teacher agency for teaching } \\
\text { science in multiple-deprived } \\
\text { classrooms }\end{array}$ \\
\hline
\end{tabular}

\subsection{Quality Measures}

In order to ensure that the findings made in this study were valid a number of steps were taken. First, rigor was ensured by using a one participant whereby longitudinal narrative data was collected based on reflections collected over two years of teaching practice. Second, the experiences were in the form of written narratives in a semi-structured format and recorded as reflections using a specially designed semi-structured guide with topics mentioned above to ensure content validity.

\section{Findings of the Study}

The data analysis of the narratives yielded six categories used to describe how conditions in multiple-deprived classrooms were influenced by, and in turn influenced the attainment of, the SDGs by the retelling of Teboho's narrative. The six categories were (i) low socioeconomic status of schools and learners, (ii) material and resource deprivation for science teaching, (iii) instructional strategy deprivation, (iv) deprivation of meaningful science-learning experience, (v) teacher agency for teaching science in multiple-deprived classrooms, and (vi) perceptions of addressing the conditions of multiple deprivation. These categories are described in the upcoming section.

\subsection{Low Socioeconomic Status of Schools and Learners}

The school that Teboho was placed in during his third year was a rural secondary school. According to how he described the school, the learners and the school's socio-economic status was low because the school lacked some of the basic science teaching facilities. Teboho said the following about the rural school: 
The school is situated in rural areas where they do not have enough access to facilities and resources. There are no computer labs, no science laboratories and students travel long distances to school. There are few learners as well as teachers. Windows [classroom windows] are broken.

In his fourth year, Teboho was placed in a township school which was also characterised by conditions of poverty. It seemed the township school had once had the facilities and resources for science teaching yet failed to maintain and replace these over time. He described the township school as follows:

The school is situated at the centre of the township. It has many vacant classrooms and labs that are no longer working. Equipment were stolen, some are broken. Some buildings are now neglected.

In this school, the science classrooms could not be run and maintained sustainably. The facilities once existed but they could not be maintained.

\subsection{Material and Resource Deprivation for Science Teaching}

The unavailability of sufficient curriculum-prescribed materials was evident from Teboho's fourth-year experience in the township when he realized that the school would not be able to secure these materials in the short term. He said the following:

Because other materials are very expensive and I cannot ask the principal to buy them, I would rather make an arrangement with schools that have all the materials and take the learners to that school so that they can perform their practical work there. Another thing, though it will take long, but I can ask the learning facilitator to help me write to the potential sponsors for donations so that the school can buy the materials.

Similarly, from his third-year experience of science teaching in the rural school, Teboho also realized that the materials and resources were not sufficient. He said:

Some ... materials were not available due to different valid reasons like theft and lack of funds in the school. Materials like the Benson burner had no gas, tripod stands were stolen, some were broken, and we even lacked the petri dish. Some were uncleaned. Not all of the materials were available; we had to come up with solutions on how to proceed with practical work while there were no materials.

Based on Teboho's experience and opinions, there were no sufficient materials for teaching science in both the schools where he was placed for practicum during his teacher preparation.

\subsection{Instructional Strategy Deprivation}

Another form of deprivation evident from Teboho's experiences was the nature of some of the instructional strategies used for science teaching. From Teboho's experiences, the instructional strategy deprivation was more evident in the township school. There, he observed the following:

The teachers [the two teaching practice mentors during teaching practice] that I have experience with were using the instruction technique where they just present a lesson and expect learners to just listen and become their vessel to fill up with knowledge.

The learners thus learnt science passively. In addition, Teboho also described how some of the syllabus-prescribed experiments were facilitated for learners in the township school. He realized that these experiments were converted from being practical work activities to theory lessons. He said:

The practicals [practical work activities] were not implemented; learners only wrote the practical activities from the teacher's guide.

However, the teacher that he observed in the rural school made an effort to at least conduct demonstrations for learners so that they could observe scientific phenomena and record their observations. Teboho said the following about the rural school:

The teacher had to use the observation method as the materials were not enough to accommodate all the learners; he had to conduct the experiment himself so that all learners could observe and take notes.

\subsection{Deprivation of Meaningful Science-Learning Experience}

Some learner-knowledge and -skills deprivations could be gleaned from some of Teboho's reflections. He felt that the learners were not familiar with some of the materials and resources that are typically prescribed for science teaching and learning and therefore would not experience some instructional strategies inherent to science teaching. He said the following from his experiences of the rural school: 
Since the school is in rural areas, there are no laboratories or equipment for practical work and learners are not familiar with some equipment. I only taught the theory, calculations and did some practical demonstrations.

Teboho described what learning opportunities the learners from the township school were deprived of. Based on his reflection on how he would improve science teaching at the township school it can be implied that the learners were deprived of meaningful experiences that would enhance their learning of science. He said:

I will use visualisation whereby a teacher brings dull scientific concepts to life with visuals and practical learning experiences, helping learners to understand how their schooling applies in the real-world. Examples include using photos, audio clips and videos, as well as encouraging learners to get out of their seats to conduct classroom experiments and local field trips.

Teboho's reflection shows that science was taught in a way that was not interesting to learners. The relevance of science to the learners' real-life experiences was not evident in the science classrooms. He also suggested how educational technologies might enhance the teaching of science if these resources were available. He further made reference to how science teaching could be extended beyond the classroom walls through experiential instructional strategies such as field trips.

\subsection{Teacher Agency for Teaching Science in Multiple-Deprived Classrooms}

During his practicum at the rural school, Teboho experienced certain material-improvisation practices that could enhance the teaching of science in multiple-deprived classrooms. He explained how some experiments were facilitated for learners even when the prescribed materials were not available. He said:

The materials were not available at school. For the experiment to be successful we had to replace some of materials with household products and borrowed some from neighbouring schools. We had to replace unavailable materials with relevant available materials; for burner, we had to use candles and for tripod, we used bricks and used a used gauze, and for petri dish, we used a lids of coffee tins.

It seems the science teacher in the rural school could find ways of not compromising the science instructional strategies when the prescribed materials were unavailable. Improvisation enabled the learners to be engaged in hands-on activities.

\subsection{Perceptions of Addressing the Conditions of Multiple Deprivation}

Finally, Teboho reflected on how he would overcome some of the challenges that he experienced during practicum in the teaching of science. He suggested ways in which he would (i) overcome the resource and material shortages, (ii) ensure learners are engaged in meaningful science learning experiences, and (iii) as a teacher, make sure he had the knowledge and skills for teaching science.

On explaining the importance of improvisation, Teboho in his own words described how he will overcome material shortages in his future science classrooms. He said:

As a teacher it is my duty for learners to understand the subject content, even if there is a lack of materials to use. As a teacher I need to provide my learners with temporary materials, such as bottle as a beaker for them to get the point of practical work by using practical example such as mixing a milk and water, things that can be found easily instead of worrying about lack of materials.

On ensuring that his learners will have meaningful science-learning experiences, he suggested that his learners will actively participate in the learning process. He said:

I would ask my learners to conduct practical activities in an investigation for a week, give them time to research on how the experiments are conducted and what observations are possible and accurate and why.

Teboho also suggested ways in which he would stay abreast with developments in the teaching and learning of science and make sure he has sufficient knowledge and skills for classroom practice. He mentioned the need for continuous professional development. He said:

For limited knowledge and skills as a science teacher I would say that I must attend more workshops and interact with other educators who have experience, who will be able to help me and lastly I would say I must also do a research about the science topics before I go to class or even try out some practical activities before I go to class.

Through Teboho's reflections, some multiple-deprived conditions in science classrooms could be identified. The 
influence of poverty on the quality of science education is notable in terms of lack of materials, in turn giving way to limited instructional strategies and learning opportunities for learners. There is an indication that teachers need to be able to find ways of overcoming the conditions of multiple deprivation to ensure meaningful science teaching.

\section{Discussion}

The study problematizes how the conditions of multiple-deprivation in the science classrooms stand in the way of SDGs attainment efforts and how science teaching in the science classrooms may be used to teach ESD in the discussion that follows. The use of one participant preservice teacher helps to show how individuals develop unique perceptions when the findings of this study are compared with similar studies.

\subsection{Connecting Multiple-Deprived Science Classrooms with SDGs as Unmet Needs}

Using the SDG on quality education (SDG 4) as an entry point, the paper sought to demonstrate that some of the unmet needs in some multiple-deprived science classrooms are inextricably connected to the imperatives on SDG achievement. Using the practicum experiences of Teboho, a physical sciences preservice teacher, in two multiple-deprived schools, it could be seen how the socio-economic status of the schools influenced the way learners experienced science teaching. Cho et al. (2014) showed that learners' poor performance can be caused by factors that stem from conditions of poverty (SDG 1). The low socio-economic status of the two schools prevented the acquisition of sufficient science teaching facilities and materials. The township school had once had some of the infrastructure and materials for science teaching in place, but these could not be maintained, possibly due to some contextual factors in the social and economic backgrounds of the community. Failure to maintain science classroom facilities because schools could not be run sustainably can be related to how cities and communities should be governed sustainably (SDG 11). Morton, Pencheon, and Squires (2017) associated the SDG on sustainable cities and communities with prosperity which the schools in this study lacked. The schools could not afford to buy the necessary materials for science teaching or replace used-up resources.

The lack of infrastructure, materials, and equipment for science teaching create tensions between the prescriptions and recommendations of how science should be taught and the teachers' choices of instructional strategies (Christie et al., 2007; Ottevanger et al., 2007; Ramnarain \& Schuster, 2014). The teaching prescriptions and recommendations in science curriculums are the same for all schools, revealing implications on SDG 10 that pertains to reduced inequalities in the society. SDG 10 seeks to promote reduced inequalities, inclusivity, and social justice which continue to be compromised in multiple-deprived science classrooms located in communities of low socioeconomic status. The socioeconomic conditions lead to other forms of unmet needs in the science classrooms. According to Teboho's experiences, instructional strategies used in science teaching became another form of deprivation in the classrooms. Science education and ESD have inherent instructional strategies to promote the spirit of inquiry, hands-on activities, practical work, and verification activities. The limited instructional strategies for science teaching brought about further deprivation in the form of meaningful science-learning challenges. Teboho could see that in the township school, science was painted as dull and uninteresting. He could also see that science teaching was not made relevant to the learners' everyday lives. From the preceding discussion, the findings show that some of the SDGs remain conditions of unmet needs in multiple-deprived science classroom environments, influencing teaching and learning. The upcoming section shows how science teaching and learning can influence the achievement of some SDGs by taking the SDG on quality education as an entry point.

\subsection{Opportunities to Teach ESD for Quality Science Classrooms}

Teboho's experiences point to a number of opportunities for teaching or implementing ESD in science classrooms in multiple-deprived environments. Failure by the township school to maintain the science teaching facilities that were once in place point to challenges in school improvement and building of sustainable schools. Mogren et al. (2019) emphasized that the implementation of whole-school ESD programs has a direct influence on the school improvement practices. In South Africa, the failure by some schools to have sound school improvement plans is blamed for the resulting dysfunctionality and reduced learner achievements (Van der Voort \& Wood, 2014). The reduced learner achievements are more pronounced in science and mathematics subjects and the situation is attributed to the influence of contextual factors stemming from the impoverished socio-economic backgrounds of schools (Cho et al., 2014; Visser, Juan, \& Feza, 2015). The whole-school-driven ESD programs present themselves as an opportune approach to support school improvement efforts. The whole-school ESD-implementation approaches also speak to the $17^{\text {th }}$ SDG that encourages the formation of partnerships as a strategy to achieve the rest of the SDGs. Schools should be able to identify and engage stakeholders in their efforts to implement whole-school ESD programs.

Teboho's reflections on his experiences of the implemented instructional strategies in the science classrooms 
displayed these strategies as a form of deprivation since they were limited. ESD comes with a number of instructional strategies that promote citizen skills for sustainability and promote sustainability topics to be part of science teaching (Burmeister et al., 2012; Kopnina, 2012). Some of these sustainability topics in the form of socio-scientific issues manifest as unmet needs in the everyday lives of the learners (Holbrook, 2009). Issues contained in the SDGs; such as imperatives to end poverty and hunger; access to affordable clean energy, clean water and sanitation; and promotion of economic growth, good health and well-being; are important immediate needs for learners from low socio-economic backgrounds. If ESD is about equipping young people with citizen skills for sustainability, these topics provide relevance and context for science teaching (Warner \& Elsier, 2015). Holbrook (2009) explained that scientific literacy should assist learners to improve their lives by making informed decisions and actions. Holbrook (2009) observed, however, that the traditional goals of science education need to be reformulated to accommodate ESD. Some of the national science curricula, such as the Curriculum and Assessment Policy Statement for Physical Sciences, already contain these socio-scientific topics strategic for the teaching of ESD (Tsakeni, 2018).

According to Teboho's reflections, one of the science instructional strategies that was difficult for the teachers to implement was practical work. However, this instructional strategy provides opportunities for teaching sustainable development (Kopnina, 2012). The teacher observed by Teboho in the rural school was able to replace some of the prescribed materials for experiments (experiments usually come with a list of materials to be used and step-by-step procedures) with locally available materials. Some of these materials are everyday household products. These products are less toxic than some of the prescribed materials for practical work activities and the practice is referred to by Andraos and Dicks (2012) as the greening of science. Tsakeni (2018) observed that some of the school syllabuses already have practical work activities in which household products are part of the prescribed materials. Teboho explained that he would not have to be worried about the unavailability of practical work materials prescribed by the syllabus if he is able to find suitable replacements from locally available materials. However, based on Teboho's experiences at the township school, the use of safer and locally available alternative materials depended on teacher agency. Some teachers do not have that agency, though, and rely on teacher-centered instructional strategies.

\section{Conclusion}

Science education goals and conditions in multiple-deprived classrooms are intricately connected to the achievement of the SDGs. In addition, science education is a crucial context to teach ESD and to achieve inclusive, equitable, and quality education. On the one hand, multiple-deprived science classrooms present adverse conditions to the facilitation of quality education as one of the SDG imperatives. Science education in multiple-deprived classrooms brings to light various factors of sustainable development, namely SDG 1, 10,11, 16, and 17 (focusing on poverty, inequalities, sustainable communities, social justice, and partnerships for sustainable development, respectively), that are unmet needs and negatively influence the attainment of quality education (SDG4). On the other hand, multiple-deprived science classrooms present opportunities to integrate SDGs with the curriculum through ESD and appropriate instructional strategies to prepare learners in sustainable development skills. As a recommendation based on Teboho's experiences, teacher training programs should make deliberate efforts to develop preservice science teacher knowledge, beliefs, and skills that support the implementation of ESD in all classroom contexts, including those characterized by conditions of multiple deprivation.

\section{Study limitations}

In spite of the justifications provided for the research design used in this study, the data were collected from one participant's narrative of his experiences and the use of multiple participants would have allowed for cross-case analysis resulting in varied insights. Since the findings are not meant to be generalized they however provide insights on how a preservice teacher may only have perceptions influenced by multiple-deprived school contexts. Based on this limitation, a recommendation is made that a similar study be conducted using multiple participants from different school environments.

\section{Acknowledgements}

The first author was supported by the National Research Foundation of South Africa through the Thuthuka Funding Instrument, and the second author was supported by the South African National Roads Agency SOC Limited (SANRAL).

\section{References}

Anastas, P. T., \& Warner, J. C. (1998). Green chemistry theory and practice. New York: Oxford University Press.

Andraos, J., \& Dicks, A. P. (2012). Green chemistry teaching in higher education: A review of effective practices. Chemistry Education Research and Practice, 13, 69-79. https://doi.org/10.1039/C1RP90065J 
Bamberg, M. (2012). Narrative analysis. In H. Cooper, P.M. Camic, D.L. Long, A.T. Panter, D. Rindskopf, \& K. Sher (Eds.), APA handbook of research methods in psychology (Vol. 2, pp. 85-102). Washington, DC: American Psychological Association.

Berglund, T. \& Gericke, N. (2016). Separated and integrated perspectives on environmental, economic and social Dimensions-An investigation of student views on sustainable development. Environmental Education Research, 22(8), 1115-1138. https://doi.org/10.1080/13504622.2015.1063589

Blom, B., \& Nygren, L. (2010). Analysing written narratives: Considerations on the 'code-totality problems'. Nordic Journal of Social Research, 1, 1-20. https://doi.org/10.7577/njsr.2035

Brod, M., Tesler, L. E., \& Christensen, T. L. (2009). Qualitative research and content validity: developing bestpractices based on science and experience. Quality of Life Research, 18(9), 1263-1278. https://doi.org/10.1007/s11136-009-9540-9

Burmeister, M., Rauch, F., \& Eilks, I. (2012). Education for sustainable development (ESD) and chemistry education. Chemistry Education Research and Practice, 13, 59-68. https://doi.org/10.1039/C1RP90060A

Chikoko, V. (2018). The nature of the deprived context: Leadership that works in deprived school contexts of South Africa. New York: Nova Science Publishers.

Cho, M. O., Scherman. V., \& Gaigher, E. (2014). Exploring differential science performance in Korea and South Africa: A multilevel analysis. Perspectives in Education, 32(4), 21-39. http://www.perspectives-in-education.com/

Christie, M., M. Carey, A. Robertson \& P. Grainger (2007). Putting transformative learning theory into practice. Australian Journal of Adult Learning, 55, 1, 9-30.

Clothey, R., Mills, M., \& Baumgarten, J. (2010). A closer look at the impact of globalization on science education. Cultural Studies of Science Education, 5, 305-313. https://doi.org/10.1007/s11422-010-9258-6

Department of Basic Education (2011). Curriculum and Assessment Policy Statement. Grades 10-12. Physical Sciences. Pretoria: Government Printing Works.

Eilks, I. (2015). Science education and education for sustainable development: Justifications, models, practices and perspectives. Eurasia Journal of Mathematics, Science \& Technology Education, 11(1), 149-158. https://doi.org/10.12973/eurasia.2015.1313a

Gustafsson, J. (2017). Single case studies vs. multiple case studies: A comparative study (Literature review). Retrieved from: http://www.diva-portal.org/smash/get/diva2:1064378/FULLTEXT01.pdf

Holbrook, J. (2009). Meeting challenges to sustainable development through science and technology education. Science Education International, 20(1/2), 44-59.

Karpudewan, M., Ismail, Z. H., \& Mohamed, N. (2009). The integration of green chemistry experiments with sustainable development concepts in the pre-service teachers' curriculum: Experiences from Malaysia. International Journal of Sustainability in Higher Education, 10(2), 118-135. https://doi.org/10.1108/14676370910945936

Karpudewan, M., Ismail, Z., \& Roth, W. M. (2012). Ensuring sustainability of tomorrow through green chemistry integrated with sustainable development concepts (SDCs). Chemistry Education Research and Practice, 13, 120-127. https://doi.org/10.1039/C1RP90066H

Kim, M., \& Tan, A. L. (2011). Rethinking difficulties of teaching inquiry-based practical work: Stories from elementary pre-service teachers. International Journal of Science Education, 33(4), 465-486. https://doi.org/10.1080/09500691003639913

Kopnina, H. (2012). Education for sustainable development (ESD): The turn away from 'environment' in environmental education? Environ. Educ. Res. 18, 699-717. https://doi.org/10.1080/13504622.2012.658028

Lunetta, V. N., Hofstein, A., \& Clough, M. P. (2007). Learning and teaching in the school science laboratory: An analysis of research, theory and practice. In S. K. Abell \& N. G. Lederman (eds). Handbook of research on $\begin{array}{lllll}\text { science } \quad \text { education, } & \text { II. } & \text { New } & \text { York: }\end{array}$ https://www.routledge.com/Handbook-of-Research-on-Science-Education-VolumeII/Lederman-Abell/p/book/978 0415629553

Maringe, F., Masinire, A., \& Nkambule, T. (2015). Distinctive features of schools in multiple deprived communities in 
South Africa: Implications for policy and leadership. Educational Management Administration and Leadership, 43(3), 363-385. https://doi.org/10.1177\%2F1741143215570303

Mogren, A., Gericke, N., \& Scherp, H. A. (2019). Whole school approaches to education for sustainable development: A model that links to school improvement. Environmental Education Research, 25(4), 508-531. https://doi.org/10.1080/13504622.2018.1455074

Morton, S., Pencheon, D., \& Squires, N. (2017). Sustainable development goals (SDGs), and their implementation: A national global framework for health, development and equity needs a systems approach at every level. British Medical Bulletin, 124(1), 81-90. https://doi.org/10.1093/bmb/ldx031

Muralikrishna, I. V., \& Manickam, V. (2017). Environmental management: Science and engineering for industry. Butterworth-Heineman.

Noble, M., Zembe, W., Wright, G., \& Avenell, D. (2013). Multiple deprivation and income poverty at small area level in South Africa in 2011. Cape Town: SASPRI.

Ottevanger, W., Van den Akker, J., \& De Feiter, L. (2007). Developing science, mathematics and ICT education in sub-Saharan Africa: Patterns and promising practices. World Bank Working Paper 101. https://doi.org/10.1596/978-0-8213-7070-4

Punch, K. (2005). Introduction to social research: Quantitative and qualitative approaches. London: Sage.

Ramnarain, U., \& Schuster, D. (2014). The pedagogical orientations of South African physical sciences teachers towards inquiry or direct instructional approaches. Research in Science Education, 44, 627-650. https://doi.org/10.1007/s11165-013-9395-5

Riessman, C. K. (2005). Narrative analysis: Narrative, memory and everyday life. Huddersfield, England: University of Huddersfield.

Schild, R. (2016). Environmental citizenship: What can political theory contribute to environmental education practice? Journal of Environmental Education, 47(1), 19-34. https://doi.org/10.1080/00958964.2015.1092417

Selod, H., \& Zenou, Y. (2003). Private versus public schools in post-apartheid South African cities: Theory and policy implications. Journal of Development Economics, 71, 351-394. https://doi.org/10.1016/S0304-3878(03)00033-6

Sipos, Y., Battisti, B., \& Grimm, K. (2008). Achieving transformative sustainability learning: Engaging head, hands and heart. International Journal of Sustainability in Higher Education, 9(1), 87-98. https://doi.org/10.1108/14676370810842193

Tsakeni, M. (2018) Opportunities for Teaching Sustainable Development through the Chemistry Component of CAPS Physical Sciences. African Journal of Research in Mathematics, Science and Technology Education, 22(1), 125-136. https://doi.org/10.1080/18117295.2018.1446498

UN (United Nations). 2015. Transforming our world: The 2030 Agenda for Sustainable Development. Retrieved from https://ec.europa.eu/environment/sustainable-development/SDGs/index_en.htm

UNECE. (2011). Learning for the future: Competences in education for sustainable development. Retrieved from https://unece.org/fileadmin/DAM/env/esd/ESD_Publications/Competences_Publication.pdf

Van der Voort, G., \& Wood, L. (2014). Assisting school management teams to construct their improvement plan: An action learning approach. South African Journal of Education, 34(3), 1-7. https://doi.org/10.15700/201409161046

Visser, M., Juan, A., \& Feza, N. (2015). Home and school resources as predictors of mathematics performance in South Africa. South African Journal of Education, 35(1), 1-10. https://doi.org/10.15700/201503062354

Warner, B. P., \& Elsier, M. (2015). How do sustainable schools integrate sustainability education? An assessment of certified K-12 schools in the United States. Journal of Environmental Education, 46(1), 1-22. https://doi.org/10.1080/00958964.2014.953020

\section{Copyrights}

Copyright for this article is retained by the author(s), with first publication rights granted to the journal.

This is an open-access article distributed under the terms and conditions of the Creative Commons Attribution license (http://creativecommons.org/licenses/by/4.0/). 